\title{
Reproductive Lifespan and Reproductive Performance in SPF C3H Mice : The Onset of Reproductive Life and Production Efficiency
}

\author{
Shizuo TOMITA, Tatsuo HAYAO, Takuya SAWADA and \\ Jun-ichiro HAYAKAWA* \\ Section of Animal and Plant Supply, Division of Technical \\ Service, National Institute of Radiological Sciences, \\ Anagawa, 4-9-1 Chiba 280, Japan and \\ *Institute for Experimental Animals, School of Medicine, \\ Kanazawa University, \\ 13-1 Takaramachi, Kanazawa 920, Japan
}

(Received for publication Sept. 13, 1977)

To improve the production system, the onset and the termination of reproductive life of $\mathrm{C} 3 \mathrm{Hf} / \mathrm{HeMsNrs}$ mice mated immediately after weaning and reared for 400 days of life, were studied. From weaning females mated with a full grown male (group A), the first litter was obtained at a mean age of 47 days, suggesting the first copulation at 26 days of age. The age of males at the first copulation was estimated to be at 44 days of age from the age giving the first litters in weanling males mated with weanling (group B) and full grown (group C) females. The sex ratio of litters delivered by young dams tended to be excess in males, The reproductive performance of dams in later life was not affected by the parturition in earlier age. The production efficiency with weaned youngs per pair during the first 200 days after mating was the highest in group A. It was found from these results that the $\mathrm{C} 3 \mathrm{H}$ females attained their sexual maturity at 5 to 6 days after weaning, being available for breeding without any deletion in reproductive performance.

\section{SPF C3H マウスの繁殖寿命と繁殖成績について: 繁殖開始時期と生産効率}

\author{
富田静男・早尾辰雄・沢田卓也・早川純一郎* \\ 放射線医学総合研究所 *金沃大学医学部附属動物実験施設
}

われわれは動物を生産する立場から動物の生物学的な 特性を知ることと, 同時にその得られた結果に基ついて, 生産效率の改善を計ることを目的として実験を行なって
いる。前報[4]では, SPF 環境で飼育繁殖しているC $3 \mathrm{H}$ マウスの 1：1 同居交配による生涯の繁殖能力と寿命に ついて検封し, 雌雄を 2 ：1で10日間交配する方式より 
もよい生産効率が得られることを報告した。

前報においては, マウスの生涯の繁殖能力を見ること を目的としたが，ほぼ同日令の成熟雌雄を用いたため， 雌雄、それぞれについて繁殖可能になる時期を決定する ことができなかった。本実験では，この点を明らかにす る目的で離乳直後の雌, あるいは雄を, それぞれ成熟し た雄と雌とを同居交配させ，繁殖可能となる時期と，そ の動物の繁殖能力を検討したので報告する。

\section{材料と方法}

動物は，放医研 SPF 動物生産施設で維持されている $\mathrm{C} 3 \mathrm{Hf} / \mathrm{HeMsNrs}$ で, 当施設内での SPF 環境の維持方 法については, 前報 [4]に詳述した。

交配群は，Table 1 に示すように，A， B， C の 3 群よりなり, A 群は平均日令25日の䊒と平均日令 62.5 日 の雄, B群は雌雄ともに平均日令25.3日, C 群では平均 日令64.7日の雌に平均日令24.6日の雄を $1 ： 1$ で交配し た。なお，前報で報告した成熟雌雄の交配による成績を 前記 3 群との比較のためにD群として示したが, D群の 雌雄同居交配日令を前報で $65 \pm 4$ 日としたが, 再計算し たところ，雌の日令は $64.0 \pm 0.7 て ゙ ，$ 雄の日令は $55.5 \pm$ 0.7 日であった。また初産日令についても，同様に前報

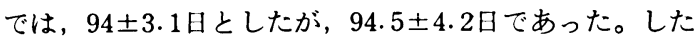
がって Table 1, Table 2 にはこれらの新しい数値を 示した。
Table 1. Mean ages of the parents in four groups when the mating was started

\begin{tabular}{ccll}
\hline Group & No. of pair & \multicolumn{2}{c}{ Mean $\pm \begin{array}{c}\text { S. E. } \\
\text { days }\end{array}$} \\
\hline A & 28 & Dam & $25.0 \pm 0.2$ \\
& & Sire & $62.5 \pm 0.2$ \\
B & \multirow{2}{*}{30} & Dam & $25.3 \pm 0.2$ \\
& & Sire & $25.3 \pm 0.2$ \\
C & \multirow{2}{*}{30} & Dam & $64.7 \pm 1.1$ \\
& \multirow{3}{*}{ D } & Sire & $24.6 \pm 0.1$ \\
& 30 & Dam & $64.0 \pm 0.7^{*}$ \\
& & Sire & $55.5 \pm 0.7^{*}$ \\
\hline
\end{tabular}

* The value of Dam plus Sire was reported to be $65 \pm 4$ days in a previous work ${ }^{4}$.

各群とも30組からなり, 雌の日令が約 400 日令に達す るまで䧳雄を同居させた。仔の産れた場合に21日令まで 雄と同居のもとで哺乳させた。A群には同居後50日以上 で妊娠しない1例がありこれは別の雄と交配した結果 雄に繁殖能力のないことが判明した。また, 同じく $\mathrm{A}$ 群 で初産後, 屋脱が見られ以後妊娠をみない1 例があっ た。他の群ではすべての組で 3 産以上の妊娠が見られて いるので，A群の前記 2 例を除外して集計した。

\section{成繶}

Table 2 に各群の初産日令と最終分婏日令および，

Table 2. Ages of dam when the first and the last litter were born, and the estimated ages of dam and sire at the copulation that resulted in the first litter in each breeding group

\begin{tabular}{|c|c|c|c|c|c|}
\hline \multirow{2}{*}{ Group } & \multirow{2}{*}{ No. of pair } & $\begin{array}{l}\text { Age at the } \\
\text { first litter }\end{array}$ & $\begin{array}{l}\text { Age at the } \\
\text { last litter }\end{array}$ & \multicolumn{2}{|c|}{$\begin{array}{l}\text { Age at the } \\
\text { copulation* }\end{array}$} \\
\hline & & Mean $\pm \underset{\text { days }}{\mathrm{S} . \mathrm{E} .}$ & 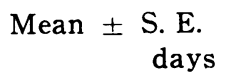 & Mean & $\pm \begin{array}{l}\text { S. } E . \\
\text { days }\end{array}$ \\
\hline \multirow[t]{2}{*}{ A } & 28 & $47.1 \pm 0.1$ & $257 \pm 10$ & Dam & $26.1 \pm 0.2$ \\
\hline & & & & Sire & $63.6 \pm 0.3$ \\
\hline \multirow[t]{2}{*}{ B } & 30 & $64.6 \pm 0.5$ & $257 \pm$ & Dam & $43.6 \pm 0.5$ \\
\hline & & & & Sire & $43.6 \pm 0.5$ \\
\hline \multirow[t]{2}{*}{$\mathrm{C}$} & 30 & $105.7 \pm 1.4$ & $289 \pm$ & Dam & $84.7 \pm 1.4$ \\
\hline & & & & Sire & $45.3 \pm 0.8$ \\
\hline \multirow[t]{2}{*}{$\mathrm{D}$} & 30 & $94.5 \pm 4.2^{* *}$ & $261 \pm 10$ & Dam & $73.5 \pm 4.3$ \\
\hline & & & & Sire & $65.0 \pm 4.2$ \\
\hline
\end{tabular}

* Estimated by the age at the first litter.

** Reported to be $94 \pm 3.1$ days in a previous work ${ }^{4}$. 
Table 3. Lifetime reproductive performance per mating pair in each breeding group

\begin{tabular}{cccccc}
\hline Group & No. of Pair & $\begin{array}{l}\text { No. of } \\
\text { parturition } \\
\text { Mean } \pm \text { S. E. }\end{array}$ & $\begin{array}{c}\text { Litter size } \\
\text { Mean } \pm \text { S. E. }\end{array}$ & $\begin{array}{l}\text { No. of pups } \\
\text { born } \\
\text { Mean } \pm \text { S. E. }\end{array}$ & $\begin{array}{l}\text { No. of pups } \\
\text { weaned } \\
\text { Mean } \pm \text { S. E. }\end{array}$ \\
\hline A & 28 & $8.3 \pm 0.4$ & $6.3 \pm 0.2$ & $52.0 \pm 2.6$ & $49.8 \pm 2.6$ \\
B & 30 & $7.8 \pm 0.4$ & $5.7 \pm 0.2$ & $44.0 \pm 2.4$ & $41.8 \pm 2.3$ \\
C & 30 & $7.3 \pm 0.3$ & $5.3 \pm 0.2$ & $37.8 \pm 2.2$ & $36.1 \pm 2.1$ \\
D & 30 & $7.0 \pm 0.4$ & $5.9 \pm 0.2$ & $40.8 \pm 2.3$ & $39.8 \pm 2.4$ \\
\hline
\end{tabular}

Table 4. Productivity in each breeding group classified by parity

\begin{tabular}{|c|c|c|c|c|c|c|c|c|c|c|c|c|c|c|}
\hline & \multicolumn{14}{|c|}{ Parity } \\
\hline & Group & 1 & 2 & 3 & 4 & 5 & 6 & 7 & 8 & 9 & 10 & 11 & 12 & Total \\
\hline \multirow{4}{*}{ 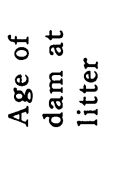 } & A & 47 & 69 & 94 & 124 & 154 & 184 & 212 & 244 & 262 & 382 & 303 & 318 & \\
\hline & $\mathrm{B}$ & 64 & 87 & 113 & 140 & 170 & 195 & 217 & 248 & 273 & 280 & 291 & 302 & \\
\hline & $\mathrm{C}$ & 105 & 130 & 153 & 177 & 206 & 240 & 265 & 293 & 313 & - & - & - & \\
\hline & $\mathrm{D}$ & 94 & 118 & 143 & 174 & 199 & 228 & 253 & 282 & 302 & 312 & - & - & \\
\hline \multirow{4}{*}{ 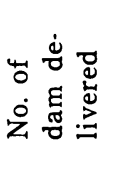 } & A & 28 & 28 & 28 & 28 & 28 & 28 & 20 & 17 & 12 & 10 & 5 & 2 & 234 \\
\hline & B & 30 & 30 & 30 & 30 & 29 & 26 & 21 & 18 & 11 & 6 & 3 & 1 & 235 \\
\hline & $\mathrm{C}$ & 30 & 30 & 30 & 27 & 27 & 27 & 22 & 15 & 9 & 1 & - & - & 218 \\
\hline & $\mathrm{D}$ & 30 & 30 & 30 & 29 & 26 & 24 & 19 & 12 & 7 & 3 & - & - & 210 \\
\hline \multirow{4}{*}{ 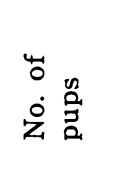 } & A & 213 & 235 & 232 & 219 & 183 & 149 & 85 & 63 & 42 & 22 & 11 & 0 & 1454 \\
\hline & B & 193 & 222 & 220 & 206 & 173 & 122 & 88 & 75 & 31 & 14 & 6 & 0 & 1350 \\
\hline & $\mathrm{C}$ & 173 & 165 & 203 & 189 & 139 & 131 & 72 & 47 & 16 & 1 & - & - & 1136 \\
\hline & $\mathrm{D}$ & 191 & 197 & 208 & 185 & 158 & 119 & 78 & 51 & 27 & 12 & - & - & 1226 \\
\hline \multirow{4}{*}{ 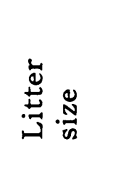 } & A & 7.6 & 8.4 & 8.3 & 7.8 & 6.5 & 5.3 & 4.3 & 3.7 & 3.5 & 2.2 & 2.2 & - & \\
\hline & B & 6.4 & 7.4 & 7.3 & 6.9 & 5.7 & 4.7 & 4.2 & 4.2 & 2.9 & 2.3 & 2.0 & - & \\
\hline & $\mathrm{C}$ & 5.8 & 5.5 & 6.8 & 7.0 & 5.1 & 4.9 & 3.3 & 3.1 & 1.8 & 1.0 & - & - & \\
\hline & $\mathrm{D}$ & 6.4 & 6.6 & 7.0 & 6.4 & 6.1 & 5.0 & 4.1 & 4.3 & 3.9 & 4.0 & - & - & \\
\hline \multirow{4}{*}{ 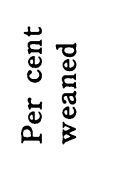 } & A & 99.8 & 90.2 & 95.6 & 93.1 & 98.3 & 98.6 & 97.6 & 98.4 & 95.2 & 90.9 & 100.0 & - & \\
\hline & B & 98.9 & 91.8 & 95.4 & 93.6 & 95.3 & 87.7 & 96.5 & 92.0 & 67.7 & 100.0 & 83.3 & - & \\
\hline & C & 98.2 & 99.3 & 94.0 & 95.7 & 99.2 & 89.3 & 77.7 & 95.7 & 93.7 & 0.0 & - & - & \\
\hline & $\mathrm{D}$ & 98.4 & 99.0 & 93.2 & 92.9 & 99.3 & 99.1 & 96.1 & 94.1 & 88.8 & 91.6 & - & - & \\
\hline
\end{tabular}

妊娠期間を21日としたときの初産の得られた雌雄の交尾 推定日令を示した。

A 群すなわち, 成熟した雄と若令の雌との交配では初 産日令は47.1日で，この初産の得られた交尾推定日令は 雌で26.1日であった。これに対して，若令の雌雄を交配 したB群では初産日令64.6日でA群に比較して17.5日お くれていた。また成熟した䊒と若令の雄の交配である C 群の雄の交尾推定日令は，44.6日であり，B群の43.6日
とほとんど同じであった。初産をした日令が異なる䊒の 400 日令まで観察結果からみた最終分婏は，若令の雄と 成熟した集の交配であるC群で約 290 日と遅くなった以 外, 他の 3 群は, 約 260 日令と同様な結果を示した。

次に，繁殖開始時期を異にする群での䊒の日令 400 日 (これは各群を通して最終分娩日令の最も遅い個体が 365 日であったことから倠の繁殖寿命が終ったと考えら れる日令である）までの繁殖成績を各群の交配当りで集 
Table 5. Sex ratio (ratio of males to females) of pups in each breeding group

\begin{tabular}{cccccccccccccc}
\hline & \multicolumn{10}{c}{ Parity } \\
Group & No. of pair & 1 & 2 & 3 & 4 & 5 & 6 & 7 & 8 & 9 & 10 & 11 & Total \\
\hline A & 28 & 1.130 & 1.061 & 1.495 & 1.489 & 0.947 & 1.129 & 1.179 & 0.750 & 1.000 & 1.750 & 0.375 & 1.165 \\
B & 30 & 1.075 & 1.114 & 1.000 & 1.123 & 0.844 & 0.820 & 0.872 & 0.923 & 0.722 & 1.142 & 0.500 & 0.987 \\
C & 30 & 1.060 & 0.737 & 0.971 & 1.100 & 1.106 & 1.183 & 1.057 & 0.741 & 1.286 & 0.000 & - & 1.000 \\
D & 30 & 0.948 & 0.989 & 1.166 & 0.989 & 1.051 & 1.061 & 0.902 & 1.125 & 1.250 & 1.000 & - & 1.026 \\
\hline
\end{tabular}

Table 6. Production efficiency of each breeding group during the first 200 days after the mating.

\begin{tabular}{ccccc}
\hline Group & No. of pair & $\begin{array}{l}\text { Total pups } \\
\text { born }\end{array}$ & $\begin{array}{l}\text { Total pups } \\
\text { weaned }\end{array}$ & $\begin{array}{l}\text { Efficiency } \\
\text { (No. of pups weaned / pair) } \\
\text { Mean } \pm \text { S. E. }\end{array}$ \\
\hline A & 28 & 1335 & 1277 & $45.6 \pm 2.0$ \\
B & 30 & 1238 & 1164 & $38.8 \pm 1.9$ \\
C & 30 & 1039 & 997 & $33.2 \pm 2.0$ \\
D & 30 & 1140 & 1114 & $37.1 \pm 2.2$ \\
\hline
\end{tabular}

計した結果を Table 3 に示した。

分婏回数は，A群では8.3，B群では7.8，C群で7.2, $\mathrm{D}$ 群で 7.0 と若令から妊娠した $\mathrm{A}$ 群が最も多かった。さ らに 1 腹仔数, 総産仔数, 離乳仔数についても, A 群が 最も多く，次いでB群となっている。したがって，交配 日令を早くすることによる慗殖能力の低下はなく，むし ろ若令からの交配によって繁殖効率は向上することが認 められた。

各群の成績をさらに詳細に比較するため, 産次ごとに 倠の平均日令, 産仔数, 1 腹仔数, 離乳仔数を Table 4 にまとめて示した。

$\mathrm{A}$ 群および $\mathrm{B}$ 群では, 倠が平均して 200 日令に達する までに 6 産が得られるのに対し，C，D群では，6産が 得られる日令がそれぞれ，240日，228日とおくれる。こ のおくれは雌の交配日令とC群では雄が交配開始時から 繁殖可能になるまでの時期に対応している。したがって， 少なくとも 6 産次までは，若令の雙を交配させることに 上る妊娠期間や妊娠間隔に差があるとは考えられない。 さらに，A群では全例が 6 産まで分婏しているのに対し， $\mathrm{B}$ 群では 4 産， C，D群では 3 産までしか全例が分婏し なかった。産仔数，1腹仔数についても，6 産次までは いずれの産次でも $\mathrm{A}$ 群が最も多い結果が得られた。ここ
で興味あることは, 各群とも, 初産の 1 腹仔数は, 2 産 あるいは 3 産に比較して少ないことで, 初産の腹仔数の 少ないことは雌親の日令と無関係であることを示してい る。

離乳率については，5産までは各群で大差がないが， $\mathrm{A}$ 群ではいずれの産次でも $90 \%$ 以上を離乳しており，若 令からの妊娠, 分婏がそれ以降の哺乳能力を低下させる 傾向は認められなかった。

得られた仔の性比に関しては, 生産動物の需要に雌雄 差があるため重要であるので, 各群の産次による性比を Table 5 に示した。

若令の䊒と成熟した雄の交配での, 早い産次では, 雄 の多くなる傾向が恋められたが，全体としては大きな差 は認められなかった。

最後に, 生産效率の点から各群を比較するため交配開 始時から200日までの各群の総産仔数, 総離乳仔数, 雌 親当りの離乳仔数を Table 6 に示した。

Table 6 から明らかなよ5に, 䧳当りの離乳仔数は平 均で $\mathrm{A}$ 群は45.6, B 群は38.8, C 群は33.2, D 群は37.1 で, A 群が最も多かった。A群の場合, 事故例として2 例を集計から除外しているが，これを加えて交配総数 30 組で計算しても交配皆当りの離乳仔数は42.5匹となり， 
もっとも効率がよい結果を示した。

\section{考察}

マウスの性成熟の時期は，性成熟の指標を何にとるか によって異なるが，どの指標をとったにしても，系統や 季節による変動の大きいものであることが指摘されてい る [1]。本実験と同様に初産日令から推定した交尾日令 については, 江崎 [2]は系統の記載はないが䧳で 30〜35 日であったことを記載している。本実験のA群, すなわ ち, 平均25日令で成熟した雄と交配した群では平均26.1 日で交尾が行われたものと推定され, 先述の報告に比較 してかなり早い。腔開口日令については系統差があり， 本実験で使用した $\mathrm{C} 3 \mathrm{H} / \mathrm{He}$ は他の系統に比較してかな り早いことが報告されている[2]が，われわれの $\mathrm{C} 3 \mathrm{Hf} /$ HeMsNrs マウスは18〜25日, 平均 20 日であることを 認めている (未発表) さらに腔開口後, 24〜120 時間で 最初に腔垢の角化が見られること, および, 最初の発情 期の交尾による妊娠率が，48～57\%といら報告がみられ る [1]。これに対して本実験, A群の28例の雌はすべて が，25〜28日令で娃娠を成立させる交尾が行なわれたも のと推定された。

以上の点から， C $3 \mathrm{H} / \mathrm{HeMsNrs}$ マウス䧳の性成熟は かなり早く，安定した性周期をしめすものと考えられ る。一方, 雄の性成熟についての報告は少いが，江崎[2] は交尾日令が40〜 45日であったことを報告している。本 実験では，若令の雌雄の交配群（B群）で平均43.6日， 成熟雌と若令雄との交配群（C 群）の結果から，44.6日 で雄の交尾が行なわれたと推定され，この結果はいずれ も，江崎の報告と大差がない。

性成熟に達すると同時に, 交尾, 妊娠, 哺乳が行なわ れた場合における動物の繁殖成績や繁殖寿命についての 報告は，われわれの知る限り，みられないので，比較で きないが，本実験では繁殖寿命の終りと考えられる 400 日令までの観察に扎いて，妊娠率，総産仔数，一腹仔 数, 離乳率のいずれにも, 若令で妊娠した雌が完全に成 熟した雌よりも良好であった。

一般に幼若な䧳を妊娠させた場合には繁殖成績が覀い といわれている $[2]$ 。その理由としては，末熟な時期の 妊娠, 哺育に伴ら負荷が細䔉感染を顕性化させるなど,

環境による母親への影響などが考えられる。長沢ら [3] は本実験と同様な $\mathrm{C} 3 \mathrm{H}$ 系統の成熟雌の繁殖成績を報告 しているが，離乳率は，本実験で得られた成熟䧳での結 果よりかなり低いこれは飼育環境によるものと思われ
る。本実験が幼若な䊒を妊娠させたにもかかわらず良好 な成績が得られたことは， $\mathrm{C} 3 \mathrm{H}$ 系統の性成熟の早さに 関連することの他に，SPF 環境下で飼育されたことに あると考えられる。

若令からの繁殖が, 将来の繁殖成績に影響しないとす れば，動物生産の立場からは，種親を育成する期間が短 縮され，きわめて有利になると考兄る。この点を本実験 結果 (Table 6) から見ると，A群とD群で交配当りの 離乳仔数をくらべると, $\mathrm{A}$ 群は D 群より $20 \%$ 程度多く, したがって，A群では，倠を離乳から繁殖に使用するま での時間と経費が節減できる。また， B 群と D群をくら べると，離乳仔数に差がみられない。しかし，B 群は倠 雄とも種親としての育成期間が短いだけ有利である。以 上, 本実験結果から， C3H では雌の性成熟は早く, 性 成熟直後からの妊娠, 哺乳は, その後の繁殖成績に悪影 響を与えず，したがって，生産効率からみて，性成熟直 後から繁殖親として使用した方が有利であることが結論 される。

\section{要 約}

成熟マウス雌あるいは雄をそれぞれ離乳直後の雌ある いは雄と同居交配させ, 繁殖可能な日令を知ることと， 若令からの交配の生産効率に与える影響を見る目的で実 験を行なった。A群は平均日令25日の雌と平均日令 62.5 日の雄, B群は雌, 雄とも平均日令25.3日, C群では平 均日令64.7日の雌に平均日令24.6日の雄を 1：1で同居 交配した。D群は同一日令成熟マウスを同様に交配した ものである。各群とも30組からなり䊒の日令が 400 日令 に達するまで同居交配させた。A群では, 初産日令は 47.1日であり, 初産の得られた交尾推定日令は倠で 26.7 日と推定される。B群では初産日令64.7日で, A群に比 較し18日遅れている。なお,この場合の若令雌の胵開口 日令は, 18〜25日で平均20日令であった。C群の雄の交 尾推定日令は, 44.6日令であり, B群とほとんど同じで ある。繁殖可能になる日令は雌では約 26 日, 雄では約 45 日であった。分娩回数は平均 $\mathrm{A}$ 群で8.3回, B群で7.8回, C 群で7.2回, D群で7.0回であり, 若令から妊娠した A 群が最も多かった。交配後 200 日間の繁殖成績からみて も，交配日令を早くすることにより，繁殖効率が向上す ることが慧められた。

この研究は一部文部省科学研究費 (特定研究『実験動物の純化 つ開発』課題番号012204 (50年度), 115104 (51年度)) の補助に よった。 
本論文を書くにあたり御助言いただいた障害基磷研究部の南 沢室長化感謝する。

\section{文献}

[1] Bronson, F. H., Dagg, C.P. and Snell, G.D. (1966). Reproduction. In Biology of the Laboratory Mouse (2nd ed.) Gree n. E. L. editor, McGrow-Hill Inc.
New York, 187-189,

［2］江崎孝三郎(1972)。各種動物の生物学。マウスとラット。 実験動物学各論, 田嶋嘉雄編, 朝倉書店東京。15-16。

［3］長沢弘, 宮本盛吉, 藤本政睛(1973)。系統マウスの繁殖成 績と計画生産について, 実験動物, 22, 119-126。

[4] 富田静男, 早尾辰雄, 内田晴康, 沢田卓也(1976)。倠雄闹 居 (1: 1) 飼育による SPF C3H マウスの繁殖成績と 寿命について, 実験動物, 25, 135-140。 